\title{
СОРАБОТКА И ФОРМИРАњЕ СТРАТЕГИСКИ СОЈУЗИ ПОМЕГ'У ТЕРОРИЗМОТ И ТРАНСНАЦИОНАЛНИОТ ОРГАНИЗИРАН КРИМИНАЛ
}

\section{Кратка содржина}

Агендата која се однесува на тероризам што се поврзува со трансначионалните организирани криминални групи постојано се проширува. Најмногу од активностите во кои терористичките групи мора да учествуваат за да ги постигнат своите чели се криминални, додека во некои случаи криминалните активности се употребуваат стратегиски како дел од механизмот за финансирање на терористичките организачии. Заемното дејство помегу тероризмот и транснаиионалниот организиран криминал станува подлабоко и покомплексно.

Овој труд ги идентификува трите главни модели на криминално/терористички интерфејс: интеракиија - алијанси за остварување заеднички профит; дискретна вмешаност на терористичките групи во организираниот криминал со елиминирање на посредникот, но одржување на идеолошките спогодби на нивната стратегија; и замена на идеологијата со профит како главен мотив за дејствување.

Во овој труд ќе се анализира еден дел од терористичко-криминалниот спектар - постојаната/редовна заедничка соработка, делење на челите и формирање стратегиски сојузи помегу терористичките групи и трансначионалните криминални организачии.

Клучни зборови: ТЕРОРИЗАМ, ТРАНСНАЦИОНАЛЕН ОРГАНИЗИРАН КРИМИНАЛ, СОРАБОТКА, СОЛУЗИ

\section{Вовед}

Со крајот на Студената војна беше дискредитиран марксизам-ленинизмот, а многу од револуционерните организации ги зафати криза на идентитет, со што ја губеа нивната raison d'etre. На попрактично ниво, некои терористички организации ја изгубија поддршката од страна на државата и мораа да пронајдат алтернативен извор на приходи. Анализите покажуваат дека започна да еродира традиционалната разлика помеѓу терористите и криминалците. Криминалците понекогаш се служат со политичко насилство за да ги заплашат владините службеници. Тоа можеше да се види во операциите за извршување атентати од страна на картелот Меделин во Колумбија и во убиствата на италијански судии кои ги изврши сицилијанската мафија. Карактеристичен е примерот со армијата Шан од Бурма, која со текот на годините од револуционерна организација еволуираше во малку повеќе од тајно здружение на шверцери на дрога. 
Во републиките на поранешниот Советски Сојуз и на Балканот, разликата помеѓу тероризмот и транснационалниот организиран криминал стана нејасна и сомнителна, инспирирајќи појава на мешани термини, како што се „криминален тероризам“ (D. Pluchinsky, 1998) и „економски тероризам“ (G. Schweitzer, C. Dorsch, 1998).

Постоењето глобални криминални мрежи за илегална трговија и трансакции обезбедува златни можности за терористичките групи (со исклучок на групите со јасни идеолошки цели) за соработка и вклучување во организирани криминални активности. Здружувањето или директната вклученост во транснационалниот организиран криминал им обезбедува на терористичките групи дополнителни финансиски средства, пристап до оружје и други потенцијални бенефиции. Заемното дејство помеѓу тероризмот и транснационалниот организиран криминал станува подлабоко и покомплексно.

Во овој труд ќе се анализира еден дел од терористичко-криминалниот спектар - постојаната/редовна заедничка соработка, делење на целите и формирање стратегиски сојузи.

\section{Заемни врски и корелации помеѓу тероризмот и транснационалниот органи- зиран криминал}

Постојат одреден вид заемни врски и корелации помеѓу тероризмот и транснационалниот организиран криминал, односно помеѓу терористичките организации и криминалните организации. Помеѓу носителите на овие појави често доаѓ до тесна соработка и симбиоза, односно поради метаморфоза на едниот проблем во друг - организираните криминални групи прибегнуваат кон терористички методи, а терористите се занимаваат со организиран криминал.

Поврзаноста помеѓу транснационалниот организиран криминал и тероризмот постои во случаи кога:

- организираниот криминал преку своите илегално стекнати профити ги финансира терористичките организации или групи;

- организираниот криминал шверцува вооружување и опрема за потребите на терористичките движења и/или шверцува странски платеници и терористи до земјите во кои дејствува терористичката организација;

- терористичките организации, самостојно или во соработка со криминалните групи, преземаат одредени организирани криминални активности заради стекнување материјални и воени средства за изведување терористички дејства;

- $\quad$ организираниот криминал, со изразени политички аспирации, презема одредени терористички активности со цел непосредно да дојде или да ја донесе својата „политичка струја“ на власт (P. R Vioti and M. V Kauppi, 1997);

- $\quad$ користат иста технологија на комуницирање; и

- д дејствуваат во области или региони во кои отсуствува целосна или цврста владина контрола. 
Тероризмот и организираниот криминал во одделни фази на развојот, се наоѓаат во причинско-последичен однос, бидејќи тероризмот ги условува и забрзува поединечните облици на криминално дејствување, кои имаат, пак, повратно дејство на целокупната терористичка активност, бидејќи се извршуваат со цел да овозможат понатамошни терористички активности.

Односот на организираниот криминал и тероризмот се манифестира низ извршување разновидни тешки кривични дела од страна на терористичките организации, најчесто заради сопствено финансирање или остварување одредени политички цели (Љ. Стајић, 2003).

Тероризмот служи за постигнување политички цели и е политички мотивиран, но не треба да се елиминира фактот дека покрај политичката, тероризмот содржи и криминална компонента. Криминалната компонента тероризмот ја остварува по пат на организирано криминално дејствување кое најчесто е за јакнење на неговата материјална основа, како битен фактор за реализација на планираните терористички активности.

Допирните точки помеѓу тероризмот и меѓународниот организиран криминал се изразуваат во различни облици на шверцување и растурање дрога, оружje, муниција, фалсификувани пари, а сѐ со цел да се финансираат терористичките активности. Во тој контекст, не смее да се испушти од вид можноста организираниот криминал, посебно оној од мафијашки тип, во остварувањето на своите цели, како и за сопствена заштита, во одделни ситуации да употреби и терористички методи, што укажува на заемната поврзаност на организираниот криминал и тероризмот (М. Бошковић, 2003).

Спрегата на транснационалниот организиран криминал и тероризмот најчесто е функционална, кога организираниот криминал се поставува во функциа на тероризмот. Истовремено, врската може да биде и инструментална, кога терористичките групи се занимаваат со организиран криминал, и обратно - кога организираните криминални групи преземаат терористички активности. Без оглед дали во одредени ситуации истите субјекти се занимаваат и со тероризам и со организиран криминал, „линијата“ помеѓу овие два феномена е јасна и недвосмислена.

\section{Модели на криминално/терористички интерфејс/интеракција}

Границите помеѓу денешните криминални и терористички светови се во постојано движење. Криминалните групи може да прераснат во терористички организации и обратно. Постојат три главни модели на криминално/терористички интерфејс/интеракција:

1) алијанси за остварување заеднички профит - во овие алијанси се вклучуваат договори со транснационални криминалци само за обезбедување финансии без да се компромитира сопствената идеологија;

2) дискретна вмешаност на терористичките групи во организираниот криминал со елиминирање на посредникот, но одржување на идеолошките спогодби на нивната стратегија; и

3) замена на идеологијата со профит како главен мотив за дејствување. 
Франк Џ. Килуфо, кој е експерт за оваа поврзаност, веќе одамна ја забележал опасноста и во 2000 година сведочел пред Конгресот, тврдејќи дека „границите помеѓу организираниот криминал, трговијата со дрога и тероризмот веќе избледнуваат" (F. Cilluffo, 2000).

Многу експерти се согласуваат со ова и ја дополнуваат оваа поврзаност како што терористите достигнуваат одредена точка на развој. Често како пример се зема неодамнешното експлоатирање на плантажите со марихуана на Филипините од страна на групата на Абу Сајаф. Како што се прекинуваат другите извори на финасирање и се прогонуваат групи на глобално ниво, терористичките ќелии дејствуваат со софистицираност на мултинационални корпорации за да создадат неверојатни количини ресурси.

Во некои случаи криминалните активности се употребуваат стратегиски како дел од механизмот за финансирање на терористичките организации. Поддржувачите на Хезболах или членовите кои биле вклучени во шверц со цигари во САД ги испратиле приходите до матичните организации. Слично, припадниците на Тамилските тигри во Канада кои биле вклучени во различни вакви криминални дејства, како што се трговија со дрога и измами со кредитни картички, средствата што ги генерирале од овие криминални дејства ги испраќале во Шри Ланка за поддршка на Тамилските тигри. Во други случаи, криминалните активности се спроведуваат тактички или се на ниво на келија и се користат за финансирање специфични терористички активности. Во мрежата на Ал-Каеда, и покрај богатството за кое се претпоставува дека го поседува организацијата, ќелиите кои ги планираат терористичките дејства добиваат малку пари од раководството. Наместо тоа, тие биле принудени да учествуваат во криминални дејства заради финансиска помош или во помали форми на организиран криминал за да ги добијат потребните финансиски средства. Други, пак, учествуваат во продажба на лажни идентитети како начин на собирање пари. Според ова, криминалните активности на терористичките ќелии кои се дизајнирани да ја одржуваат ќелијата и да обезбедат финансии може да значат дека ќелијата се подготвува да дејствува. Сепак, постои дополнителен пресврт. Во европската мрежа на Ал-Каеда, од 2000 до 2002 година, се појавила поделба на трудот помеѓу ќелиите со што некои од нив имале јасно дефинирана оперативна функција, а другите имале јасна функција да обезбедуваат финансиска поддршка. Со други зборови, криминалните активности на една ќелија се дел од структурата за поддршка на друга ќелија. Ваквата поделба на трудот во една мала матрица, главно, резултира со еднонасочен проток на пари. Ова е индикатор за тоа која ќелија се подготвува да дејствува. Сепак, во некои случаи, криминалната активност остава трага која им овозможува на истражителите и разузнавачките аналитичари да ги поврзат фактите и да добијат појасна слика за барем еден сегмент од целокупната терористичка мрежа.

Некои автори ја застапуваат тезата дека транснационалниот организиран криминал и тероризмот не конвергираат во единствен феномен. Тие развиваат блиски релации и формираат верига/врска на организиран криминал и тероризам (P. Williams, 1998). Но, разликата помеѓу овие две појави не треба да се замаглува. Тие сѐ уште имаат различни цели - политичка промена (тероризмот) и акумулаци- 
ја на богатство (организиран криминал). Нивните разидувачки намери и приоритети претставуваат потенцијален извор на тензија помеѓу нив. Соработката е повеќе веројатна да биде поделена/расцепкана и привремена отколку планска и долгорочна. низации:

Постојат пет главни трендови во организацијата на терористичките орга-

1) трендот на масовни напади со бомбардирање;

2) трендот на масовни напади со голем број жртви;

3) трендот на напади креирани со цел да нанесат огромни штети на националната економија, дали преку бомбардирање на клучни финансиски и комерцијални области или, пак, со напади на ранливи клучни сектори. (на пример, терористички напади на туристичката индустрија во Египет и во Турција);

4) во многу земји постои огромен пораст на киднапирања со земање заложници со цел да се изнудуваат пари од семејства, компании и влади; и

5) трендот на сѐ поблиска врска и тесна соработка на политичките со терористичките групи и транснационалниот организиран криминал (на пример, алијанси помеѓу герилата на Колумбија и лордовите на дрога).

Интеракцијата на транснационалниот организиран криминал со тероризмот нуди рути за шверцување кои се долго утврдени и тестирани од страна на криминалните синдикати за дрога и трговија со оружје, потенцијално обезбедувајќи ги терористите со логистичка инфраструктура за тајно движење на луѓето, оружјето и материјалите (N. Pollard, 1999).

Терористичките акции понекогаш се наједноставен параван за прагматичните криминални активности. Затоа не е случајно што терористички акти се извршуваат во делови на светот во кои се преклопуваат интересите на државите или на мултинационалните компании за контрола над значајни природни ресурси или други добра над кои е ослабена државната контрола од некои причини.

Постои соработка во одредени случаи кога терористите имаат потреба од обезбедување криминални услуги, за работи како што се фалсификувани документи и способност за трговија со луѓе. Врските на снабдување во кои се вклучени дрога и оружје, исто така, се развиени, поттикнати од заедничка придобивка и можност. Сепак, можноста за потесна соработка помеѓу терористите и криминалците не смее да биде занемарена. Едно место каде што е можно да се остварат вакви врски, секако, е затворот, каде што се зацврстуваат заедничките механизми што можат да доведат до непосакувани сојузи веднаш штом затворениците ќе излезат од него. Во некои случаи, членовите на криминалните организации ги зачувуваат врските со терористите и на тој начин обезбедуваат оружје или логистичка поддршка која ќе биде големо олеснување во реализирањето на терористичкиот напад. Сепак, во други случаи, криминалците можат да се наклонат кон исламот и да го прифатат глобалниот џихад. Во вакви случаи, не се работи за соработка, туку за интеграција. Еден ваков пример се случи во Шпанија каде што членовите на малите, но добро организирани марокански организации за трговија со дрога, предводени од Џамал Ахмидон, станаа радикални и последователно на тоа беа 
приклучени кон келии кои беа одговорни и го спроведоа бомбашкиот напад во Мадрид. Тешко е да се процени колкав беше придонесот на радикалните трговци со дрога: обезбедија финансии и логистика која им овозможи на ќелиите да дојдат до експлозивните средства. Без нивните извори и помош, тешко е да се претпостави дали воопшто би се случиле нападите на возовите, а сигурно тие не би биле со толкава деструктивна моќ. Овој тренд на преминување кон радикализмот на криминалците се засили и во Западна Европа и во САД, и со сигурност ќе го зголеми капацитетот на терористичките организации и на нивните напади со голем број жртви (J. Baylis, J. Wirtz, C. Gray, E. Cohen at al, 2007).

Ако соработката меќу криминалец и терорист е опасен тренд, во последно време друг феномен станува уште поочигледен - користење методи на организираниот криминал од страна на терористи со цел пристап до финансиски средства. Како што САД и меѓународната заедница ги спречија организациите кои ги финансираа терористичките активности, така Ал-Каеда и збратимените ќелии и мрежи беа принудени да се потпрат на свои извори на финансирање. Групата Абу Сајаф на Филипините се финансира со помош на киднапирање и изнудување, како и преку умерено вклучување во трговија со дрога. Ваквиот тренд сѐ повеќе се забележува во Западна Европа. Заедно со трговијата на дрога и измамите од секаков вид, се еден тип индустрија која е во подем кај европскиот џихад. Популарни се измамите со фалсификувани кредитни картички, производство на мобилни телефони и кражби кои се профитабилни, но ретко кога го привлекуваат вниманието на властите. Покрај тоа, џихадистите се длабоко инволвирани во трговијата со луŕe, активност во која воспоставија кооперативни врски со неаполската Камора (D. E Kaplan, 2005). Колку повеќе терористите се однесуваат како криминалци со цел да соберат финансии за своите активности, толку повеќе се зголемува можноста тие да стапат во контакт и соработка со традиционалните криминалните организации кои се заинтересирани за профит, а не за политика. Меѓутоа, треба секогаш да се има предвид дека тие егзистираат и функционираат како посебни, релативно самостојни појави и дека нивната релација може да биде на ниво на поврзаност преку формирање стратегиски сојузи.

Прашањето дали постои симбиоза помеѓу тероризмот и транснационалниот организиран криминал крие неколку слоја на истражување за два сложени феномена во политичка смисла. Во непосредна смисла постои директна врска помеѓу двете: многу од терористичките акти се и самите криминални. Ова прашање добива повеќе внимание во последните неколку години отколку во минатото. Но, ова не значи дека поради ова подобро разбираме како терористичките групи се вмешуваат во обичен криминал и повремено во криминални групи или како нивната вмешаност го обликува нивниот развој и нивните активности.

Од друга страна, се поставува прашањето дали и до колкава мера терористите се вмешани во други форми на криминал. Во тој поглед, постојат најмалку два начина во кои терористите настојуваат инструментално да се вовлекуваат во обичниот криминал.

Прво, во отсуство на други мерки на поддршка, тие се вмешуваат во раз- 
лични форми на профитен конвенционален криминал, доходовен или предаторски, со цел да се одржуваат самите и да ги финансираат своите главни активности.

Второ, во отсуство на нормален пристап до некои од средствата што им се потребни за да ги спроведат своите терористички активности, тие се вмешуваат во различен криминал со цел да набават такви средства. Различни форми на човечка експлоатација и конвенционален криминал, кој вклучува и учество во експлоатирање на различни нелегални пазари, станува предуслов за спроведувањето успешни терористички операции. Државното спонзорство на тероризмот кое се намалило во последните неколку години влијае на самофинансирање со помош на криминал (I. Bantekas, 2003). Криминалот станал потреба на терористичките групи кога се исцрпени другите извори на финансирање.

Оттаму произлегува дека сојузите и различните форми на соучество и колаборација би можеле да се формираат помеѓу терористичките групи и конвенционалните криминални организации, особено оние што дејствуваат на меѓународно ниво. Овие закани се вистински и се базираат на примери на привремени, но, сепак, многу опасни сојузи помеѓ трговци со дрога и вооружени терористички групи.

\section{Заклучок}

Соработката помеѓу терористите и криминалците е поочекувано да се појави под соодветни услови. На пример, поствоените општества и пропаднати држави овозможуваат совршени услови за соединување на криминални и терористички активности. Кога авторитетот на државата е разорен, резултира со еден вакуум кој би можел да се искористи од страна на организираните криминални групи и политичките групи. Потенцијалот за соработка во овој случај се зголемува.'

Процесите кога терористичкиот ентитет станува криминално здружение и вице верза се возможни. Како што е анализирано во овој труд, тоа може да се случи преку директна форма или преку формирање хибридна организација. Подоцна, политичките и криминалните димензии се помешани што прави невозможно една група да се однесува како политички или само како криминален актер. Иако соработката помеѓу терористичките и криминалните групи не е незначајна, трансформацијата е онаа која е поверојатна отколку формирањето сојузи. Терористичките групи можат да се трансформираат во транснационални криминални организации кога ќе бидат заинтересирани за профит, дури и кога постои политичка мотивација.

Може да се заклучи дека главната загриженост за иднината може и да не произлезе толку многу од поврзаноста помеѓу терористите и криминалците, туку од трансформацијата на терористичките групи во главно криминални, односно групи чиј главен приоритет се финансиска добивка, а не идеолошки цели. Денес, ваквите хибридни закани и ваквото трансформирање на терористичките групи во хибридни криминално-терористички ентитети се доста чести.

\footnotetext{
${ }^{1}$ Карактеристичен е целиот Балкански регион како опасна зона на политичко-криминални поврзувања.
} 


\section{Литература}

Baylis, John, Wirtz, James, Gray, S Colin, Cohen Eliot at al, (2007). Strategy in the contemporary world, Oxford University Press.

Bantekas, Ilias (2003). The International Law of Terrorist Financing, The American Jour

Бошковић, Мићо (2003). Транснационални организовани криминалитет, Полицијска академија, Београд.

Cilluffo, Frank (2000). The Threat Posed from the Convergence of Organized Crime, Drug Trafficking, and Terrorism, U.S. House Committee on the Judiciary.

Kaplan, E. David (2005). The New Business of Terror, US News and World Report.

Pollard, Neal (1999), Terrorism and Transnational Organized Crime: Implications of Convergence, The Terrorism Research Center September Essay, dostapno na: (www.terrorism.com/terrorism/crime.htm).

Pluchinsky, A. Dennis (1998). Terrorism in the Former Soviet Union: A Primer, a Puzzle, a Prognosis, Studies in Conflict \& Terrorism 21

Schweitzer E. Glenn and Dorsch, C. Carole (1998), Super terrorism: Assassins, Mobsters, and Weapons of Mass Destruction, New York and London, Plenum Press.

Стајић, Љубомир (2003). Основи безбедности, Полициска академија, Београд.

Vioti R. Paul and Kauppi, V. Mark (1997). International Relations and World PoliticsSecurity, Economy, Identity, Prentice Hall, New Jersey.

Williams, Phil (1998). Terrorism and Organized Crime: Convergence, Nexus, or Transformation? Gunnar Jervas (ed), FOA Report on Terrorism, Stockholm: FOA. 
Tanja MLOSHEVSKA

\section{COOPERATION AND CREATING STRATEGIC ALLIANCES BETWEEN TERRORISM AND TRANSNATIONAL ORGANIZED CRIME}

\section{Summary}

Agenda concerning terrorism, which is associated with transnational organized crime groups, are constantly expanding. Most of the activities that terrorist groups must participate in order to achieve their goals are criminal, while in some cases criminal activity is used strategically as part of the mechanism to finance terrorist organizations. Interaction between terrorism and transnational organized crime is becoming deeper and more complex.

This paper identifies three main models of criminal / terrorist interface: Interaction - alliances to achieve mutual profit; discreet involvement of terrorist groups in organized crime by eliminating the middleman but maintaining the ideological conventions of their strategy and replacement of ideology with a profit as the main motive for action.

In this paper, we analyse one part of the terrorist - criminal spectrum - the permanent / regular cooperation, sharing objectives and the formation of strategic alliances between terrorist groups and transnational criminal organizations.

Keywords: TERRORISM, TRANSNATIONAL ORGANIZED CRIME, NEXUS, AND ALLIANCES. 